\title{
PERKEMBANGAN DAN DINAMIKA SUBJEK SANGKETA \\ ANTROPOLOGI HUKUM
}

\author{
PUTRI MUTIA SARI \\ Email: putrimutiasari03@gmail.com \\ No BP:2110003600007 \\ UNIVERSITAS EKASAKTI \\ PADANG
}

\section{A .PENDAHULUAN}

Masyarakat hukum adat menurut peraturan perundang-undangan secara tegas mengakui keberadaannya. Berdasarkan pasal 18B ayat 2 undang-undang dasar tahun 1945, yaitu : Negara mengakui dan menghormati kesatuan - kesatuan masyarakat hukum adat serta hak-hak tradisionalnya sepanjang masih hidup dan sesuai dengan perkembangan masyarakat dan prinsip Negara kesatuan Republik Indonesia, yang diatur dalam undang - undang. Hukum adat adalah hukum yang bersumber pada ugeran - ugeran atau norma - norma kehidupan sehari - hari yang langsung timbul sebagai pernyataan kebudayaan orang Indonesia asli dalam dalam hal ini sebagai pernyataan rasa keadilan dalam hubungan pamrih, sehingga jelas sekali terlihat bahwa hukum adat adalah hukum asli bangsa Indonesia sendiri secara turun menurun , berdasarkan value counciousness mereka yang termanifestasi dalam kebiasaan - kebiasaan hidup sehari - hari dengan menggunakan ukuran nalar dan rasa keadilan mereka.

6 sistem peradilan orang sumatera berbeda dengan orang eropa. Mengikuti system peradilan orang sumatera, kedua belah pihak yang bertikai jarang memberikan pertanyaan - pertanyaan . bahkan saksipun tidak harus mengucapkan sumpah sebelumnya. Bila suatu fakta di jabarkan , baik dari pihak pendakwa maupun terdakwa, keabsahan peristiwa lah yang di pertanyakan. 


\section{B. PEMBAHASAN}

sangketa adalah suatu situasi dimana ada pihak yang merasa dirugikan oleh pihak lain, yang kemudian pihak tersebut menyampaikan ketidak puasan ini kepada pihak kedua. Jika situasi menunjukkan perbedaan pendapat,maka terjadilah apa yang di namakan dengan sangketa. Dalam konteks hukum khususnya hukum kontrak ,yang dimaksud dengan sangketa adalah perselisihan yang terjadi antara para pihak karena adanya pelanggaran terhadap kesepakatan yang telah dituangkan dalam suatu kontrak, baik sebagian maupun keseluruhan. Dengan kata lain telah terjadi wanprestasi oleh pihak-pihak atau salah satu pihak.(Nurnaningsih amriani,2012 ;12).

Pada hakikatnya proses sangketa antropologi hukum adalah suatu rangkaian proses yang di lakukan untuk mendapatkan penyelesaian suatu sangketa. Proses penyelesaian sangkeya terdiri dari dua cara yaitu melalui litigasi (pengadilan) dan non litigasi ( luar pengadilan ). Sangketa dapat terjadi pada siapa saja dan dimana saja. Sangketa dapat terjadi antara individu dengan individu, antara individu dengan kelompok, antara kelompok dengan kelompok, antara perusahaan dengan perusahaan dan lain sebagainya.

Sangketa merupakan suatu masalah sosial yang bersifat universal, karena itu , konflik tidak perlu dilihat sebagai gejala patologis yang bersumber dari tingkah laku abnormal atau indikasi dari suatu kekacauan dalam dinamika kehidupan masyarakat, karena setiap komunitas masyarakat mempunyai kapasitas untuk menciptakan norma- norma dan mekanisme- mekanisme tersendiri untuk menyelesaikan sangketa yang muncul dalam pergaulan sosial warga masyarakat (Nader, 1968; Coser, 1968; Roberts, 1979, Moore, 1978). Dari perspektif antropologi hukum , fenomena sangketa mempunyai makna ganda yaitu : disatu sisi sangketa mempunyai makna menimbulkan 
perpecahan atau disintegrasi suatu kehidupan sosial, melemahkan kohesi sosial atau menimbulkan kerusakan suatu sistem hubungan sosial dalam masyarakat. Tetapi, disis lain sangketa juga memiliki makna positif dalam mempertahankan integrasi sosial, memperkokoh ikatan sosial dan memberikan kontribusi untuk mengembalikan keseimbangan hubungan sosial dan memberi kontribusi untuk mengembalikan keseimbangan hubungan sosial antar individu atau kelompok dalam masyarakat. Yang disebutkan terakhir dalam terwujud apabila pihak pihak yang bersengketa secara bersama-sama dapat mengelola,mengendalikan ,dan menyelesaikan sangketa yang dihadapi secara dewasa, bijak dan damai dengan atau tanpa mengundang kehadiran pihak ketiga (Gluckman, 1956). Dengan kata lain ,dari perspektif antropologi hukum dikatakan sangketa tidak selalu bermakna negative dalam kehidupan masyarakat, karena sangketa juga mempunyai makna positif yang dapat memperkokoh integrasi dan kohesi hubungan sosial dalam masyarakat atau mengembalikan keseimbangan hubungan dan sendir - sendi kehidupan sosial. Jadi , sesungguhnya sangketa yang terjadu dalam masyarakat mengandung arti yang konstruktif dan bersifat integrative, karena sangketa juga mempunyai kekuatan tersendiri untuk membentuk, mengembangkan ,menertibkan ulang suatu relasi sosial, interaksi ,atau tatanan kehidupan yang sudag ada dalam masyarakat (Roberts, 1978). Berikut ini beberapa teori tentang sebab-sebab timbulnya sangketa, antara lain :

a. Teori hubungan masyarakat, menitik beratkan adanya ketidakpercayaan dan rivalisasi kelompok dalam masyarakat. Para penganut teori ini memberikan solusi - solusi terhadap konflik - konflik yang timbul dengan cara peningkatan komunikasi dan saling pengertian antara kelompok - kelompok yang mengalami konflik ,serta pengembangan toleransi agar masyarakat lebih bisa saling menerima keberagaman dalam masyarakat( Takdir Rahmadi ,2011:8 ) 
b. Teori negosiasi prinsip teori negosiasi prinsip menjelaskan bahwa konflik terjadi karena adanya perbedaan-perbedaan diantara para pihak. Para penganjur teori ini berpendapat bahwa sebuah konflik dapat diselesaikan, maka pelaku harus mampu memisahkan perasaan pribadinya dengan masalah - masalah dan mampu melakukan negosiasi berdasarkan kepentingan dan bukan pasa posisi yang sudah tetap (Takdir Rahmadi (2011 : 8 )

c. Teori identitas teori ini menjelaskan bahwa konflik terjadi karena sekelompok orang merasakan identitasnya terancam oleh pihak lain. Penganut teori identitas mengusulkan lokakarya dan dialog antara wakil - wakil kelompok yang terancam dilakukan melalui fasilitasi tujuan mengidentifikasikan ancaman-ancaman dan kekhawatiran yang mereka rasakan serta membangun empati dan rekonsiliasi. Tujuan akhirnya adalah pencapaian kesepakatan bersama yang mengakui identitas pokok semua pihak (Takdir Rahmadi , $2011: 9)$

d. Teori kesalahpahaman antar budaya teori kesalahpahaman antar budaya menjelaskan bahwa konflik terjadi karena ketidak cocokkan dalam berkomunikasi diantara orang orang dari latar belakang budaya yang berbeda. Untuk itu, diperlukan dialog antara masyarakat lainnya, mengurangi empati da rekonsiliasi. Tujuan akhirnya adalah pencapaian kesepakatan bersama yang mengakui identitas pokok semua pihak.(Takdir Rahmadi, 2011:9)

e. Teori tansformasi teori ini menjelaskan bahwa konflik dapat terjadi karena adanya masalah - masalah ketidaksetaraan dan ketidakadilan serta kesenjangan yang terwujud daam berbagai aspek kehidupan masyarakat baik sosial, ekonomi maupun politik. Penganut teori ini berpendapat bahwa penyelesaian konflik dapat dilakukan melalui 
beberapa upaya seperti perubahan struktur dan kerangka kerja yang menyebabkan ketidak setaraan, peningkatan hubungan ,dan sikap jangka panjang para pihak yang mengalami konflik, serta pengembangan proses - proses dan sistem untuk mewujudkan pemberdayaan, keadilan ,rekonsiliasi dan pengakuan keberadaan masing - masing (Takdir Rahmadi $2011: 9$ )

f. Teori kebutuhan atau kepentiangan manusia. Pada intinya teori ini mengungkapkan bahwa konflik dapat terjadi karena kebutuhan atau kepentingan manusia tidak dapat terpenuhi / terhalangi atau merasa dihalangi oleh orang / pihak lain. Kebutuhan dan kepentingan manusia dapat dibedakan menjadi tiga jenis yaitu subtantif ,procedural, dan psikologis. Kepentingan subtantif (substantive) berkaitan dengan kebutuhan manusiayang berhubungan dengan kebendaan seperti uang, 20 sandang, pangan , papan/rumah dan kekayaan. Kepentingan procedural ( procedural) berkaitan dengan tata dalam pergaulan masyarakat, sedangkan kepentingan psikologis (psychological) berhubungan dengan non-materil atau bukan kebendaan seperti penghargaan dan empati (Takdir Rahmadi, $2011: 10)$.

Tema -tema kajian yang dominan pada fase awal perkembangan antropologi hukum berkisar pada pertanyaan - pertanyaan : apa kah hukum itu ? apakah ada hukum dalam masyarakat yang bersahaja , tradisional, dan kesukuan ? bagaimanakah hukum berwujud dan beroperasi dalam kehidupan masyarakat? pada decade tahun 1940-an sampai 1950-an tema-tema kajian antropologi hukum mulai tergeser ke mekanisme - mekanisme penyelesaian sangketa dalam masyarakat sederhana /bersahaja. Karya klasik dari Llewwllyn dan Hoebel bertajuk The Cheyenne (1941) merupakan hasil studi lapangan kolaborasi dari seorang sarjana hukum dengan 
ahli masyarakat suku kemudian, Hoebel mempiblikasikan The Law Of Primitiv Man (1968), disusul dengan karya Glickman mengenai hukum orang Barotst dan Lozi di afrka , karya Bohannan mengenai hkum orang Tiv, karya Gulliver mengenai hukum orang Arusha dan Ndendeuli. Karya fallers mengenai hukum dalam masyarakat suku soga, dan karya pospisil tentang hukum orang kapauku di papua.

Fase perkembangan tema studi antropologi hukum kearah mekanisme - mekanisme penyelesaian sangketa seperti yang disebutkan diatas disebut oleh F.von benda -Beckmann (1989) sebagai fase the anthropology of dispute settlements. Pada decade tahun 1960 -an tema studi -studi antropologi lebih memberi perhatian pada fenomena kemajemukan hukum atau plurarisme hukum. Tema plurarisme hukum pertama - tama difocuskan pada kemajemukan cara - cara penyelesaian melalui mekanisme tradisional dan institusi penyelesaian sangketa menurut hukum pemerintah colonial dan pemerintah Negara-negara yang sudah merdeka. Karya Bohannan , Gluckman, dan Gulliver misalnya, tidak secara sistematis memberi perhatian pada eksistensi mekanisme dan institusi penyelesaian sangketa menurut hukum colonial dan hukum NegaraNegara sedang berkembang.

Sejak tahun 1970- an tema studi - studi antroplogi hukum secara sistematis difocuskan pada hubungan antar institusi - isntitusi peneyelesaian sangketa secara tradisional , neo - tradisional dan menurut institusi hukum Negara. Karya nader dan Todd (1978) misalnya memfocuskan kajian pada proses, mekanisme,dan institusi - institusi penyelesaian sangketa di komunitas masyarakat tradisional dan modern di beberapa Negara di dunia, melalui Berkeley village law projects, menjadi karya yang memperlihatkan kecenderungan baru dari topik - topik studi antropologi hukum. Publikasi lain yang perlu dicatat adalah mekanisme penyelesaian sangketa di kalangan orang togo di afrika karya f. von benda - Beckmann (1979) dan k. von benda- 
beckmann (1984) yang member pemahaman tentanf penyelesaian sangketa harta warisan di kalangan orang minan kabau menurut pengadilan adat di pengadilan negeri di sumatera barat.

\section{PENUTUP}

Proses sangketa dalam antropologi hukum merupakan suatu hal yang ahrus memiliki strategi dan cara yang dapat di terapkan dalam menyelesaikan suatu sangketa. Strateginya antara lain opsi hukum (hukum adat, hukum Negara, maupun surat perjanjian ) dan opse model resolusi konflik (negosiasim mediasi dan lainnya).sangketa adalah suatu situasi dimana ada pihak yang merasa dirugukan oleh pihak lain, yang kemudian pihak tersebut menyampaikan ketidakpuasan ini kepada pihak kedua.jika situasi menunjukkan perbedaan pendapat, maka terjadilah apa yang dinamakan sangketa. Dalam konteks hukum khususnya hukum kontrak, yang dimaksud dengan sangketa adalah perselisihan yang terjadi antara para pihak karena adanya pelanggaran terhadap kesepakatan yang telah dituangkan dalam suatu kontrak, baik sebagian maupun keseluruhan.

Dengan kata lain terjadu wanprestasi oleh pihak - pihak atau salah satu pihak.

\section{DAFTAR PUSTAKA}

Darmini Roza dan Laurensius Arliman S, Peran Pemerintah Daerah Di Dalam Melindungi Hak Anak Di Indonesia, Masalah-Masalah Hukum, Volume 47, Nomor 1, 2018. https://doi.org/10.14710/mmh.47.1.2018.10-21

Laurensius Arliman S, Peranan Metodologi Penelitian Hukum di Dalam Perkembangan Ilmu Hukum di Indonesia, Soumatera Law Review, Volume 1, Nomor 1, 201. http://doi.org/10.22216/soumlaw.v1i1.3346.

Laurensius Arliman S, Peran Badan Permusyawaratan Desa di Dalam Pembangunan Desa dan Pengawasan Keuangan Desa, Padjadjaran Journal of Law, Volume 4, Nomor 3, 2017. https://doi.org/10.15408/jch.v4i2.3433.

Laurensius Arliman S, Penanaman Modal Asing Di Sumatera Barat Berdasarkan Undang- Undang Nomor 25 Tahun 2007 Tentang Penanaman Modal, Supremasi Hukum, Volume 1, Nomor 1, 2018. http://dx.doi.org/10.36441/hukum.v1i01.102 .

Laurensius Arliman S, Memperkuat Kearifan Lokal Untuk Menangkal Intoleransi UmatBeragama Di Indonesia, Ensiklopedia of Journal, Volume 1, Nomor 1, 2018, https://doi.org/10.33559/eoj.v1i1.18. 
Laurensius Arliman S, Perkawinan Antar Negara Di Indonesia Berdasarkan Hukum Perdata Internasional, Kertha Patrika, Volume 39, Nomor 3, 2017, https://doi.org/10.24843/KP.2017.v39.i03.p03.

Laurensius Arliman S, Partisipasi Masyarakat Di Dalam Pengelolaan Uang Desa PascaUndangUndang Nomor 6 Tahun 2014 Tentang Desa, Jurnal Arena Hukum, Volume 12, Nomor 2, 2019, https://doi.org/10.21776/ub.arenahukum.2019.01202.5.

Laurensius Arliman S, Mewujudkan Penegakan Hukum Yang Baik Di Negara Hukum Indonesia, Dialogica Jurnalica, Volume 11, Nomor 1, 2019, https://doi.org/10.28932/di.v11i1.1831.

Laurensius Arliman S, Mediasi Melalui Pendekatan Mufakat Sebagai Lembaga Alternatif Penyelesaian Sengketa Untuk Mendukung Pembangunan Ekonomi Nasional, UIR Law Review, Volume 2, Nomor 2, 2018, https://doi.org/10.25299/uirlrev.2018.vol2(02).1587

Laurensius Arliman S, Peranan Filsafat Hukum Dalam Perlindungan Hak Anak Yang Berkelanjutan Sebagai Bagian Dari Hak Asasi Manusia, Doctrinal, Volume 1, Nomor 2,2016.

Laurensius Arliman S, Ni Putu Eka Dewi, Protection of Children and Women's Rights in Indonesiathrough International Regulation Ratification, Journal of Innovation, Creativity and Change Volume 15, Nomor 6, 2021.

Laurensius Arliman S, Gagalnya Perlindungan Anak Sebagai Salah Satu Bagian Dari Hak Asasi Manusia Oleh Orang Tua Ditinjau Dari Mazhab Utilitarianisme, Jurnal Yuridis, Volume 3, Nomor 2, 2016, http://dx.doi.org/10.35586/.v3i2.180.

Laurensius Arliman S, Tantangan Pendidikan Kewarganegaraan Pada Revolusi 4.0, Jurnal Ensiklopedia Sosial Review, Volume 2, Nomor 3, 2020. 